\title{
Enterprenuerial Motivation Amongst University Students in Pakistan: Proposing and Testing a Mediation Model
}

\author{
Muhammad Ali Ahmad \\ Email: m.ali.ahmad-2018@feb.unair.ac.id \\ Syed Alamdar Ali Shah \\ Email: alamdar2000pk@yahoo.com \\ Waqar Ahmed Mallah \\ Email: waqar.mallah2011@gmail.com \\ Muhammad Saud \\ Email: muhhammad.saud@gmail.com
}

\begin{abstract}
Objective of this research is to explore factors that contribute towards entrepreneurial motivation amongst university students in Pakistan. Data of 500 respondents from HEC recognized universities in Pakistan has been collected and analyzed for the purpose of our research. Data has been gathered from students of different degree programs commerce, business administration, banking and finance, and marketing department of public and private universities of Pakistan. A mediation model has been proposed and tested in order to achieve our objectives. Data has been analyzed using different econometric and statistical techniques. The results suggest that there exists some "psychological" and "economic" factors that influence the entrepreneurial motivation of university students in Pakistan. Over and above, there also that exits a group of psychological factors that partially mediate in our model.
\end{abstract}

Keywords: Entrepreneurship, Entrepreneurial Motivation, Mediation Model, Psychological Factors, Economic Factors

\section{INTRODUCTION}

Entrepreneurship plays a vital role in economy by providing opportunities under the dynamic environment to the society (Neck and Greene, 2011). It develops the country's economic cycle which automatically deals with the unemployment problem which every developing country have through which country have through which country improves their economic condition and makes betterment in every field (Mohar, Singh and Kamal ,2007). Young generation is attracted to being an entrepreneur than to do a job in a specific field. Universities play the best part for the entrepreneurial environment as these institutions are focus on new ideas and creative innovativeness (Edmondson and McManus, 2007). Entrepreneurship opens and broader the ways that students wants to owned a business or 
becoming self-employed with the creative mind and changed behavior (Thompson, 2009). It is still in exploratory stage that need to get maximum and result of research and conflicts in the way of entrepreneurship (Colette, 2015).

The main concentration of the study to understand the concept of entrepreneurship and their main drivers of motivation among university students of Pakistan that how knowledge base improve and enhance the entrepreneurship motivation like knowledge of business management and how entrepreneurial competencies effect the entrepreneurial motivation like behavior and skills of individual and how entrepreneurial attitudes affect entrepreneurial motivation like what point of view of an individual towards entrepreneurial motivation. The behavior attribute approach focuses on the appearances of specific persons expected that the exclusive conventional of structures that more improve the entrepreneurial motivation activities (cope, 2015).

In this way, a great part of the examination to date does not give unequivocal exact help to the view that enterprise instruction increments entrepreneurial inspiration. Accordingly, a need exists to build up extra research that may elucidate this point by examining conceivable clarifications for the conflicting outcomes saw in exact examinations (Colette, 2015). In an under developed country like Pakistan, importance of entrepreneurship grows by many fold. However, unfortunately Pakistan's economy is severely lacking in such activities. There are multiple reasons for this which includes both psychological and hardcore factors. In Pakistan, only government is expected to take initiatives and for the setup of new establishments. Thus in order to encourage entrepreneurial activities in Pakistan, it is imperative that along with modifying the Mercantilist role of government, ideology and behavior of people also needs to be altered as well.

The main focus of this study is to measure how different factors influence 'Entrepreneurial Intentions' among the business students or young graduates those who are about to enter in the labor/ job market. For this selected behavioral variables; entrepreneurial knowledge, professional attraction, social valuation, entrepreneurial capacity, entrepreneurial capacity is used as determinants of entrepreneurial intentions among young entrepreneurs. Apart from these behavioral variables demographics and father's education is also included the estimated model. The study aims to provide useful implications for educational institutions within the field of business and management, and for government policy makers.

The findings of this research is to add whether situational factors, for example, the sort obviously, the degree level, and the length of the business enterprise course can likewise go about as an indicator of entrepreneurial inspiration among college understudies. For business visionaries, particularly University understudies can take in such a large number of things from the discoveries as it will give proposals to their improvement. This study therefore has the following main objective: To explore the factors which effect entrepreneurial motivation among university students of Pakistan. This main objective shall be explored with the help of exploring the following sub objectives:

- To examine whether perception of the student about his personal success has any effect on entrepreneurial motivation of the student (EM1). To examine whether perception of the student about his personal fulfillment has any effect on entrepreneurial motivation of the student (EM2).

- To examine whether perception of the student about economic wealth acquisition has any effect on entrepreneurial motivation of the student (EM5).

- To examine whether perception of the student about achieving comfort in life has any effect on entrepreneurial motivation of the student (EM7).

- To examine whether perception of the student about his increment in personal income has any effect on entrepreneurial motivation of the student (EM8). 
- To examine whether perception of the student about his intention to become his own boss has any effect on entrepreneurial motivation of the student (EM11).

- To examine whether perception of the student about power to make his own decision has any effect on entrepreneurial motivation of the student (EM12).

- To examine whether perception of the student about participation in decision making process has any effect on entrepreneurial motivation of the student (EM13).

- To examine whether perception of the student about securing his future has any effect on entrepreneurial motivation of the student (EM14).

\section{LITERATURE REVIEW}

Basu and Virick (2008) evaluated entrepreneurial intentions and their antecedents. Their findings highlight that education and prior experience does have a positive and significant impact on entrepreneurial behavior. Obembe, Otesile and Ukpong (2014) explained the student's points of view towards the idea of business enterprise, the different variables that shape the students' viewpoints and the part of the college foundation in developing an entrepreneurial soul of students. Utilizing calculated various leveled relapse, the impact of four factors that could influence students' enterprise recognition, for example, Capital, University Education, Survival and Familiarity are resolved. Discoveries have uncovered that these elements establish a noteworthy determinant of the students' entrepreneurial viewpoints, which this investigation subsequently base on speculation.

Yurtkoru, Kuşcu and Doğanay(2014) explored the effect of relevant factors on entrepreneurial goal of college understudies. Hypothesis of Planned Behavior Model (TPB) is utilized as a hypothetical structure, since ongoing writing recommends that aims can anticipate future enterprise. Logical components which are social, instructive and auxiliary help are considered as precursors of individual state of mind and saw conduct control, consequently they are required to affect entrepreneurial goal. The outcomes of Ismail et al., (2015) demonstrate that entrepreneurial introduction of staff and understudies is having more impact towards commercialization of research than entrepreneurial expectation alone. The examination adds to the current assemblage of writing identified with enterprise and the idea of entrepreneurial college.

Hassan et al., (2018) showed that dynamic educating and learning approach has critical association with an entrepreneurial goal and enthusiasm among understudies. Moreover, dynamic educating and learning approach included proactive components that support basic reasoning and critical thinking ability among understudies. To execute this approach, this investigation proposes Entrepreneurial Creative Card (EC-Card) as a major aspect of classroom exercises. Mat, Maat and Mohd (2015) recognized the elements that influencing the entrepreneurial goal among designing innovation understudies. The discoveries uncovered that the factor that contributes the most to business enterprise expectation is Locus of control, trailed by Need of Achievement and Subjective Norms. Kadir, Salim and Kamarudin (2012) coordinated to choose the association between enlightening help and entrepreneurial desires.

Van Gelderen et al., (2008) exhibited a point by point observational examination of the entrepreneurial aims of business understudies. They utilize the Theory of Planned Behavior (TPB) and the outcomes demonstrate that the two most critical factors to clarify entrepreneurial goals are entrepreneurial sharpness and the significance appended to money related security. Schlaegel and Koeing (2014) said that Increasing enthusiasm for the improvement of entrepreneurial expectations has raised the significance of hypotheses that foresee and disclose people's inclination to begin a firm. Moreover, our discoveries 
recommend that the incorporated model gives extra logical power and a fuller comprehension of the procedure through which entrepreneurial expectation creates.

Bae et al., (2014) characterized the examination on enterprise educationentrepreneurial expectations has yielded blended outcomes. They additionally dissected mediators, for example, the qualities of business enterprise training, understudies' disparities, and social qualities. Our outcomes have suggestions for business enterprise training researchers, program evaluators, and approach creators. Muhammad, Aliyu and Ahmed (2015) explained that Entrepreneurial goal (EI) is one of the major contributing variables to the arrangement, development and advancement of business. It advances independence and achieves activities. Business then again, has been considered as a motor of development for financial development and improvement of created and rising economies. Scholastic exchanges and approach activities are expanding these days on the indispensable part of entrepreneurial improvement in a general public.

Rasli et al., (2013) demonstrated that work understanding, vicarious experience, general disposition, picture of enterprise and other statistic factors are tried against entrepreneurial conviction and entrepreneurial aims. This examination underpins the suggestion that conviction is the most grounded variable that has coordinate impact towards entrepreneurial aim, while general demeanor has a huge impact and in addition those male understudies with work encounter were found to have higher entrepreneurial aim.

Adekiya and Ibrahim (2016) analyzed the impact of business preparing program and social introduction on the expectation of understudies to take part in entrepreneurial practices. The outcome from the relapse investigation led shows that apparent suitability, saw viability and entrepreneurial preparing, except for apparent consistence have a positive and critical impact on entrepreneurial expectation. Farhangmehr, Gonçalves, \& Sarmento (2016) uncovered that business enterprise skills are an indicator of business inspiration however that learning base isn't. Furthermore, enterprise training does not enhance the inspiration of college understudies to wind up business visionaries.

Noor Hasnah (2014) analyzed factors influencing the behavior towards entrepreneurship among the higher education students in UniKL, Malaysian Spanish Institute. Multiple Regression Analysis shows the results that all the independent variable except the desirability to self-employment and government role have the significant relationship with the attitude towards entrepreneurship. This is supported by a study made by Wang and Wong (2004) which stated that dreams of many students lose momentum by the lack of preparation by the academic institutions. Internal factors like willingness to take risks need for independence and locus of control are studied by Franke and Luthje (2004). They also investigated some external factors like market, education, training, network, society, inspiration likely to affect student intention to be an entrepreneur.

Luthje and Franke (2003) distinguished the reasons for entrepreneurial purpose among building understudies. In particular, we investigate whether enduring individual auras or whether view of relevant establishing conditions affect the expectation to establish one's own business. The review of 512 understudies at the MIT School of Engineering extensively affirms the model. Identity characteristics strongly affect the state of mind towards independent work. The entrepreneurial mentality is firmly connected with the aim to begin another wander. The understudies' identity consequently demonstrates a circuitous impact on goals. Besides, the entrepreneurial expectation is straightforwardly influenced by seen obstructions and bolster factors in the business related setting. The discoveries have vital ramifications for strategy producers inside and outside colleges.

Franke and Luthje (2004) acknowledged that the instructive arrangement of colleges needs to give a scholarly situation that may fill in as an impetus for high-innovation new companies. The scholarly custom of business in German-talking nations is short. Up to this 
point, cultivating advancements and new item improvement through business has not been viewed as an essential assignment of colleges. Be that as it may, points of view have changed in this regard, and there have been various endeavors to upgrade the part of college graduates as originators of creative organizations. In this paper, we look at the entrepreneurial goals of understudies at two German-talking colleges (the Vienna University of Economics and Business Administration and the University of Munich) with the relating results for a main organization in this field: Massachusetts Institute of Technology (MIT). We find exceptionally particular examples of entrepreneurial soul in these colleges. The outcomes additionally recommend that the lower level of establishing expectations among understudies in Munich and Vienna might be credited to their less unmistakable business enterprise instruction. This leaves a lot of opportunity to get better.

However, in entrepreneurship it effects both positively and negatively on the work which wants to be self-employed or entrepreneur. The environment, social networking and culture create a close relationship between attitudes, competencies, knowledge base and behavior towards entrepreneurship. According to the researcher Luthje (2004) he examines that university play a major role to create an impact on students who wants to become an entrepreneur. Therefore, an individual person with the positive actions towards the creation of revenues may be more positive to become a self-employed.

After seen this situation the country creating a trend and motivate their young generation and students to become an entrepreneur then to do job in a specific field which ultimately improve the living stander of the students and through this country improves its economic conditions (Garba,Kabir,and Nalado,2014). In this context the entrepreneurship creates the link between motivation with entrepreneurial attitudes, motivation with entrepreneurial competencies, motivation and knowledge base. There are many factors that influence behavior and also indicate that how hard a person is willingness to try to do a business.

Yurtkoru, Kuşcu and Doğanay (2014) explored the effect of relevant factors on entrepreneurial goal of college understudies. This investigation utilized adjusted Theory of Planned Behavior show in clarifying entrepreneurial expectation by wiping out abstract standard as an immediate impact on entrepreneurial goal. As indicated by our outcomes, individual disposition and saw conduct control anticipated the entrepreneurial expectation; in any case, state of mind had a significantly more grounded impact. Hypothesis of Planned Behavior Model (TPB) is utilized as a hypothetical structure, since ongoing writing recommends that aims can anticipate future enterprise. Logical components which are social, instructive and auxiliary help are considered as precursors of individual state of mind and saw conduct control, consequently they are required to affect entrepreneurial goal. The model is tried on 425 college understudies. Our outcomes give valuable ramifications to strategy producers and teachers.

Ismail et al., (2015) examination is directed on an example of respondents having a place with one research college of Malaysia. The outcomes demonstrate that entrepreneurial introduction of staff and understudies is having more impact towards commercialization of research than entrepreneurial expectation alone. The outcomes additionally demonstrate that the staff and understudies are having a solid entrepreneurial mentality. The examination adds to the current assemblage of writing identified with enterprise and the idea of entrepreneurial college.

Based on the literature review and research objectives we establish the following hypotheses for the purpose of our research:

\section{Null Hypothesis:}


Ho: There does not exist any relationship between Entrepreneurial Motivation, Intention to become own boss, Participation in decision making process, Securing Personal future, Power to make decisions, Personal Success, Personal Income, Personal Economic Wealth, Comfort in Life, Personal Fulfilment and Personal Profit Opportunities.

\section{Alternative Hypotheses:}

H1: Intention of the student to become his own boss positively effects Entrepreneurial Motivation of the university students.

H2: Intention of the student for participation in decision process positively effects Entrepreneurial Motivation of the university students.

H3: Intention of the student about securing family future positively effects Entrepreneurial Motivation of the university students.

H4: Intention of the student power to make decision positively effects Entrepreneurial Motivation of the university students.

H5: Intention of the student about personal success positively effects Entrepreneurial Motivation of the university students.

H6: Intention of the student about increasing personal income positively effects Entrepreneurial Motivation of the university students.

H7: Intention of the student personal economic wealth positively effects Entrepreneurial Motivation of the university students.

H8: Intention of the student about comfortable life positively effects Entrepreneurial Motivation of the university students.

H9: Intention of the student personal fulfilment positively effects Entrepreneurial Motivation of the university students.

H10: Intention of the student about personal profit opportunities positively effects Entrepreneurial Motivation of the university students. research:

Besides we also evaluate the following mediating hypotheses for the purpose of our

H11: Intention of the student to become his own boss positively effects Power to make decisions of the university students.

H12: Intention of the student about participation in decision process positively effects Power to make decisions of the university students.

H13: Intention of the student about securing family future positively effects Power to make decisions of the university students.

H14: Power to make decisions of the student fully mediates the relationship between independent variables and Entrepreneurial Motivation amongst university students of Pakistan.

H15: Power to make decisions of the student partially mediates the relationship between independent variables and Entrepreneurial Motivation amongst university students of Pakistan. 
Figure 1: Mediation Model of Entrepreneurial Motivation

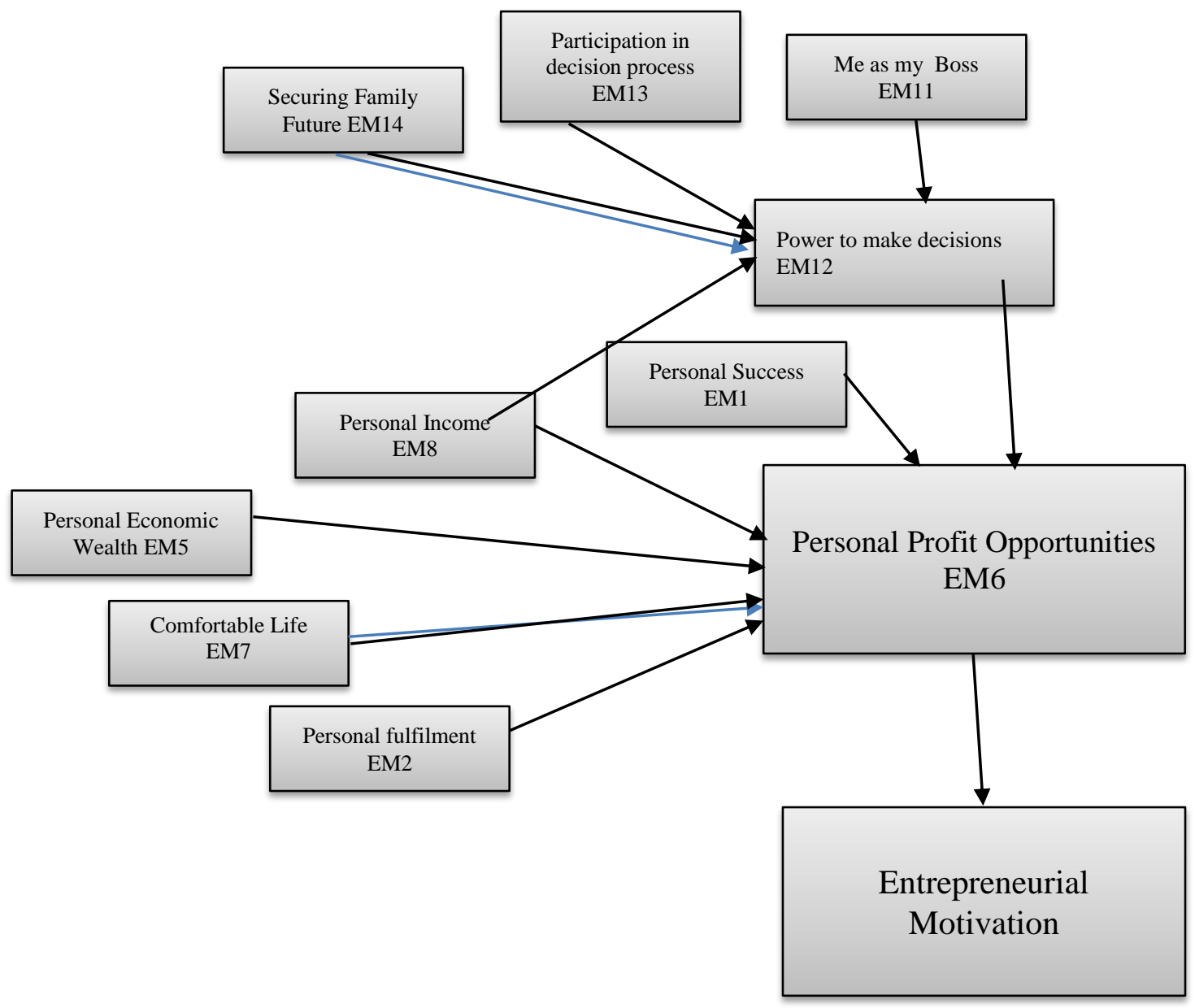

\section{METHODOLOGY}

Keeping in view the nature of research problem and objectives we have employed quantitative methodology to secure data. Data was gathered using closed-ended questionnaire according to objectives of research. After the pre-testing and re-designing of the questionnaire, final survey was conduct in different areas of the Pakistan to get the desired information from the University Students of Pakistan. Respondents for this study were selected on the basis of convenience sampling method, a type of non-random sampling technique. In order to check sampling adequacy, we applied KMO and Bartlett's test, calculated communalities and also computed total variance explained using principal component analysis using varimox rotation technique. In order to check internal consistency of data we applied Cronbach's alpha. We have also computed correlations to check relationship between data and finally applied multiple regression analysis to check our mediating model.

\section{RESULT AND DISCUSSION}

Table: 1 Descriptive Statistics

\begin{tabular}{|c|c|c|c|c|}
\hline Gender & \multicolumn{2}{|c|}{$41 \%$ Male } & \multicolumn{2}{|c|}{$59 \%$ Female } \\
\hline Age Group & \multicolumn{2}{|c|}{ Below $2571 \%$} & \multicolumn{2}{|c|}{ Above $2529 \%$} \\
\hline Level of Education & \multicolumn{2}{|c|}{ U Grad 65\% } & \multicolumn{2}{|c|}{ P Grad 35\% } \\
\hline Family Education & U Matric 33\% & College $28 \%$ & Bachelors $23 \%$ & Masters $16 \%$ \\
\hline
\end{tabular}




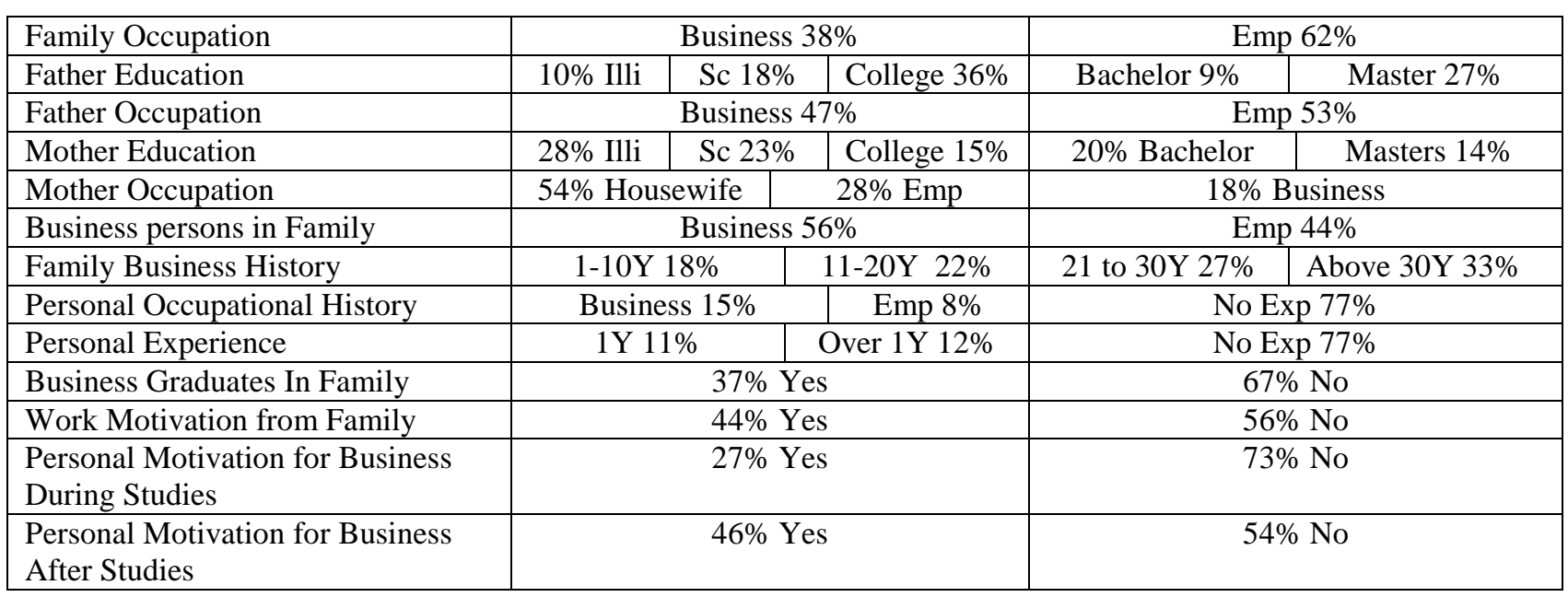

Family means Parents and Siblings

\section{Explanation:}

The table 1 explains descriptive statistics of the participants of our study. The table shows $59 \%$ of our respondents were females, $71 \%$ were below 25years of age and $65 \%$ of our respondents were undergraduates. $61 \%$ of our respondents declared that atleast one member of their family except her/him-selves have upto college level education and 39\% responded that atleast one person from their family has upto university level education. $36 \%$ of the respondents responded that their fathers have upto university level education, and $34 \%$ of the responded that their mothers have upto university level education. $10 \%$ and $28 \%$ of the respondents respectively responded that their fathers and mothers are illiterate. 38\% respondents responded that atleast one person from their family is doing business. $47 \%$ of the respondents responded that their fathers are doing business, $18 \%$ of the respondents responded that their mothers are doing business and $56 \%$ of the respondents responded that one of their family member is doing business. $60 \%$ of the respondents responded that their one of their family member has more than 20 years of business experience. $23 \%$ of the respondents responded that they have some sort of working experience. $37 \%$ of the respondents responded that there is atleast one business graduate in their family. $44 \%$ of the respondents responded to have work motivation from their families during studies. Lastly, $27 \%$ of the respondents responded to have intention to establish businesses during their studies and $46 \%$ of the respondents responded to have intention to establish businesses after their studies.

Table: 2 KMO and Bartlett's Test

Kaiser-Meyer-Olkin Measure of Sampling 0.817 Adequacy:

Bartlett's Test of Approx. Chi-Square 6127.327 Sphecity

Table 3: Communalities

Entrepreneurial Motivation

\begin{tabular}{lll}
\hline Enables me to prove that I can be successful :EM1 & 0.541 & 0.623 \\
\hline Enables my personal fulfilment :EM2 & 0.742 & 0.767 \\
\hline Allows me to face challenges :EM3 & 0.577 & 0.626 \\
\hline Is exciting :EM4 & 0.636 & 0.661 \\
\hline Allows me to acquire economic wealth :EM5 & 0.821 & 0.944 \\
\hline Makes it possible to increase opportunities for profit :EM6 & 0.711 & 0.774 \\
\hline Allows me to get a comfortable life :EM7 & 0.549 & 0.581 \\
\hline Helps me to increase personal income :EM8 & 0.627 & 0.636 \\
\hline Enables me to get public recognition :EM9 & 0.675 & 0.713 \\
\hline Allows me to afford independence :EM10 & 0.795 & 0.848 \\
\hline Allows me to be my own boss :EM11 & 0.818 & 0.854
\end{tabular}


Allows me to have the power to make decisions :EM12

$0.663 \quad 0.724$

Allows me to participate in the whole decision-making process :EM13 $\quad 0.874 \quad 0.913$

\begin{tabular}{llll}
\hline Allows me to ensure a secure future for the family :E14 & 0.744 & 0.787
\end{tabular}

Enables increased funding for retirement :EM15

$0.546 \quad 0.616$

Extraction Method: Principal Component Method

Table 4: Descriptive Analysis for entrepreneur motivation

Entrepreneurial Motivation

Enables me to prove that I can be successful :EM1

Enables my personal fulfilment :EM2

Allows me to face challenges :EM3

Is exciting :EM4

Allows me to acquire economic wealth :EM5

Makes it possible to increase opportunities for profit :EM6

Allows me to get a comfortable life :EM7

N Mean Std. deviation

Helps me to increase personal income :EM8

$\begin{array}{lll}500 & 4.43 & .944\end{array}$

Enables me to get public recognition :EM9

$\begin{array}{lll}500 & 4.01 & .969\end{array}$

Allows me to afford independence :EM10

$\begin{array}{lll}500 & 4.03 & .965\end{array}$

Allows me to be my own boss :EM11

Allows me to have the power to make decisions :EM12

$\begin{array}{lll}500 & 3.49 & 1.309\end{array}$

$\begin{array}{lll}500 & 3.64 & 1.089\end{array}$

$500 \quad 3.73 \quad 1.041$

$500 \quad 3.83 \quad 1.214$

$500 \quad 3.64 \quad 1.172$

Allows me to participate in the whole decision-making process :EM13

Allows me to ensure a secure future for the family :E14

Enables increased funding for retirement :EM15

Source: Survey Results

\begin{tabular}{lll}
500 & 3.43 & 1.292 \\
\hline 500 & 3.65 & 1.204 \\
\hline 500 & 3.74 & 1.287 \\
\hline 500 & 3.90 & 1.104 \\
\hline 500 & 3.99 & 1.120 \\
\hline 500 & 3.76 & 1.202 \\
\hline 500 & 3.57 & 1.368
\end{tabular}

Table 5: Total Variance Explained

Factor Initial Eigen Values $\quad$ Extraction Sum of Squared Rotation Sum of Squared Loadings

\begin{tabular}{|c|c|c|c|c|c|c|c|c|c|}
\hline & Total & $\begin{array}{l}\% \text { of } \\
\text { Variance }\end{array}$ & $\begin{array}{l}\text { Cumulative } \\
\%\end{array}$ & Total & $\begin{array}{l}\% \text { of } \\
\text { Variance }\end{array}$ & $\begin{array}{l}\text { Cumulative } \\
\%\end{array}$ & Total & $\begin{array}{l}\% \text { of } \\
\text { Variance }\end{array}$ & $\begin{array}{l}\text { Cumulative } \\
\%\end{array}$ \\
\hline 1 & 6.714 & $52.743 \%$ & $52.743 \%$ & 6.143 & $49.635 \%$ & $39.635 \%$ & 3.072 & $24.818 \%$ & $24.818 \%$ \\
\hline 2 & 1.331 & $17.145 \%$ & $58.888 \%$ & 0.843 & $10.435 \%$ & $52.070 \%$ & 2.417 & $21.221 \%$ & $46.039 \%$ \\
\hline 3 & 1.227 & $9.643 \%$ & $68.531 \%$ & 0.614 & $4.732 \%$ & $56.802 \%$ & 2.231 & $10.763 \%$ & $56.802 \%$ \\
\hline
\end{tabular}

Extraction Method: Principal Component Method

Table 6: Reliability Statistics

\begin{tabular}{|c|c|c|c|}
\hline & $\begin{array}{l}\text { Cronbach's } \\
\text { alpha }\end{array}$ & $\begin{array}{l}\text { Cronbach's } \\
\text { alpha } \\
\text { Std Items }\end{array}$ & $\mathbf{N}$ \\
\hline Enables me to prove that I can be successful :EM1 & 0.735 & 0.712 & 500 \\
\hline Enables my personal fulfilment :EM2 & 0.747 & 0.752 & 500 \\
\hline Allows me to face challenges :EM3 & 0.722 & 0.733 & 500 \\
\hline Is exciting :EM4 & 0.847 & 0.819 & 500 \\
\hline Allows me to acquire economic wealth :EM5 & 0.934 & 0.901 & 500 \\
\hline Makes it possible to increase opportunities for profit :EM6 & 0.783 & 0.767 & 500 \\
\hline Allows me to get a comfortable life :EM7 & 0.841 & 0.856 & 500 \\
\hline Helps me to increase personal income :EM8 & 0.835 & 0.857 & 500 \\
\hline Enables me to get public recognition :EM9 & 0.725 & 0.754 & 500 \\
\hline Allows me to afford independence :EM10 & 0.945 & 0.911 & 500 \\
\hline Allows me to be my own boss :EM11 & 0.731 & 0.722 & 500 \\
\hline Allows me to have the power to make decisions :EM12 & 0.856 & 0.834 & 500 \\
\hline Allows me to participate in the whole decision-making process :EM13 & 0.784 & 0.790 & 500 \\
\hline Allows me to ensure a secure future for the family :E14 & 0.765 & 0.771 & 500 \\
\hline Enables increased funding for retirement :EM15 & 0.842 & 0.813 & 500 \\
\hline
\end{tabular}




\begin{tabular}{|c|c|c|c|c|c|c|c|c|c|c|c|c|c|c|c|c|}
\hline \multirow[b]{2}{*}{$\begin{array}{l}\text { Pearson } \\
\text { Correlation }\end{array}$} & \multicolumn{16}{|c|}{ Factors of Entrepreneurial Motivation } \\
\hline & & EM1 & EM2 & EM3 & EM4 & EM5 & EM6 & EM7 & EM8 & EM 9 & EM10 & EM11 & EM12 & EM13 & EM14 & EM15 \\
\hline \multirow[t]{2}{*}{ EM1 } & Corel & 1 & $.632^{* *}$ & $.375^{* * 3}$ & $.214^{* * *}$ & $.320^{* *}$ & $.370^{* *}$ & $.282^{* * *}$ & .116 & $.163^{*}$ & .119 & -.101 & .041 & .022 & $.251^{* * *}$ & .116 \\
\hline & Sig & & 000 & .000 & .009 & .000 & .000 & .000 & .159 & .046 & .146 & .217 & .616 & .792 & .002 & .157 \\
\hline \multirow[t]{2}{*}{ EM2 } & Corel & & 1 & $.444^{* *}$ & $.280^{* * *}$ & $.259^{* *}$ & $.363^{* * *}$ & $.190^{*}$ & .158 & $.226^{* *}$ & .131 & -.046 & .127 & .062 & $.227^{* * *}$ & $.207^{*}$ \\
\hline & Sig & & & .000 & .001 & .001 & .000 & .020 & .054 & .005 & .111 & .579 & .122 & .452 & .005 & .011 \\
\hline \multirow[t]{2}{*}{ EM3 } & Corel & & & 1 & $.300^{3 * *}$ & $.254^{* * *}$ & $.256^{* *}$ & $.268^{* * *}$ & $.290^{* * *}$ & $.198^{*}$ & .131 & $\begin{array}{l}.009 \\
\end{array}$ & .035 & .093 & $.192^{*}$ & .107 \\
\hline & Sig & & & & .000 & .002 & .002 & .001 & .000 & .015 & .109 & .911 & .674 & .256 & .019 & .191 \\
\hline \multirow[t]{2}{*}{ EM4 } & Corel & & & & 1 & $.366^{* *}$ & .132 & .118 & .064 & $.240^{* *}$ & $\mathbf{3 0 1}^{* * *}$ & .132 & .085 & -.025 & $.285^{* *}$ & $.399^{* *}$ \\
\hline & Sig & & & & & .000 & .108 & .152 & .436 & .003 & .000 & .106 & .299 & .760 & .000 & .000 \\
\hline \multirow[t]{2}{*}{ EM5 } & Corel & & & & & 1 & $.329^{* * *}$ & $.344^{* *}$ & .103 & $.253^{* *}$ & $.278^{* * *}$ & $.163^{*}$ & .104 & .059 & $.380^{* * *}$ & $.266^{* * *}$ \\
\hline & Sig & & & & & & .000 & .000 & .210 & .002 & .001 & .047 & .206 & .477 & .000 & .001 \\
\hline \multirow[t]{2}{*}{ EM6 } & Corel & & & & & & 1 & $.431^{* * *}$ & $.339^{2 *}$ & $.255^{* *}$ & .092 & .148 & $.228^{* *}$ & .073 & $.270^{* * *}$ & $.254^{* * *}$ \\
\hline & Sig & & & & & & & .000 & .000 & .002 & .264 & .070 & .005 & .373 & .001 & .002 \\
\hline \multirow[t]{2}{*}{ EM7 } & Corel & & & & & & & 1 & $.484^{2 * 2}$ & $.253^{* *}$ & $.225^{* *}$ & .070 & $.202^{*}$ & $.236^{* *}$ & $.316^{* * *}$ & $.222^{* *}$ \\
\hline & Sig & & & & & & & & .000 & .002 & .006 & .396 & .013 & .004 & .000 & .006 \\
\hline \multirow[t]{2}{*}{ EM8 } & Corel & & & & & & & & 1 & $.311^{* *}$ & $.168^{*}$ & .080 & .330 $^{* * *}$ & $.208^{*}$ & $.229^{* * *}$ & .092 \\
\hline & Sig & & & & & & & & & $\begin{array}{c}.000 \\
\end{array}$ & .040 & .331 & .000 & .011 & .005 & .263 \\
\hline \multirow[t]{2}{*}{ EM9 } & Corel & & & & & & & & & 1 & $.411^{* *}$ & $.249^{* * *}$ & .101 & .090 & $.174^{*}$ & $.252^{* *}$ \\
\hline & Sig & & & & & & & & & & .000 & .002 & .220 & .273 & .033 & .002 \\
\hline \multirow[t]{2}{*}{ EM10 } & Corel & & & & & & & & & & 1 & $\mathbf{. 3 2 3}^{* * *}$ & .120 & .043 & $.257^{* * *}$ & $.285^{* *}$ \\
\hline & Sig & & & & & & & & & & & .000 & .143 & .601 & .001 & .000 \\
\hline \multirow[t]{2}{*}{$\overline{\text { EM11 }}$} & Corel & & & & & & & & & & & 1 &. $\mathbf{3 9 3}^{* * *}$ & .106 & .137 & $.329^{* * *}$ \\
\hline & Sig & & & & & & & & & & & & .000 & .197 & .094 & .000 \\
\hline \multirow[t]{2}{*}{ EM12 } & Corel & & & & & & & & & & & & 1 & $.412^{* *}$ & $.356^{* *}$ & $.212^{* * 3}$ \\
\hline & Sig & & & & & & & & & & & & & .000 & .000 & .009 \\
\hline \multirow[t]{2}{*}{ EM13 } & Corel & & & & & & & & & & & & & 1 & $.278^{* *}$ & $.173^{*}$ \\
\hline & Sig & & & & & & & & & & & & & & .001 & .034 \\
\hline \multirow[t]{2}{*}{ EM14 } & Corel & & & & & & & & & & & & & & 1 & $.590^{* *}$ \\
\hline & Sig & & & & & & & & & & & & & & & .000 \\
\hline EM15 & Corel & & & & & & & & & & & & & & & 1 \\
\hline $\begin{array}{l}* * \text {. Correla } \\
\text { (2-tailed). }\end{array}$ & $\begin{array}{l}\text { Sig } \\
\mathrm{n} \text { is si }\end{array}$ & & 0. & & & & & & & & & & & & 0.05 & \\
\hline
\end{tabular}




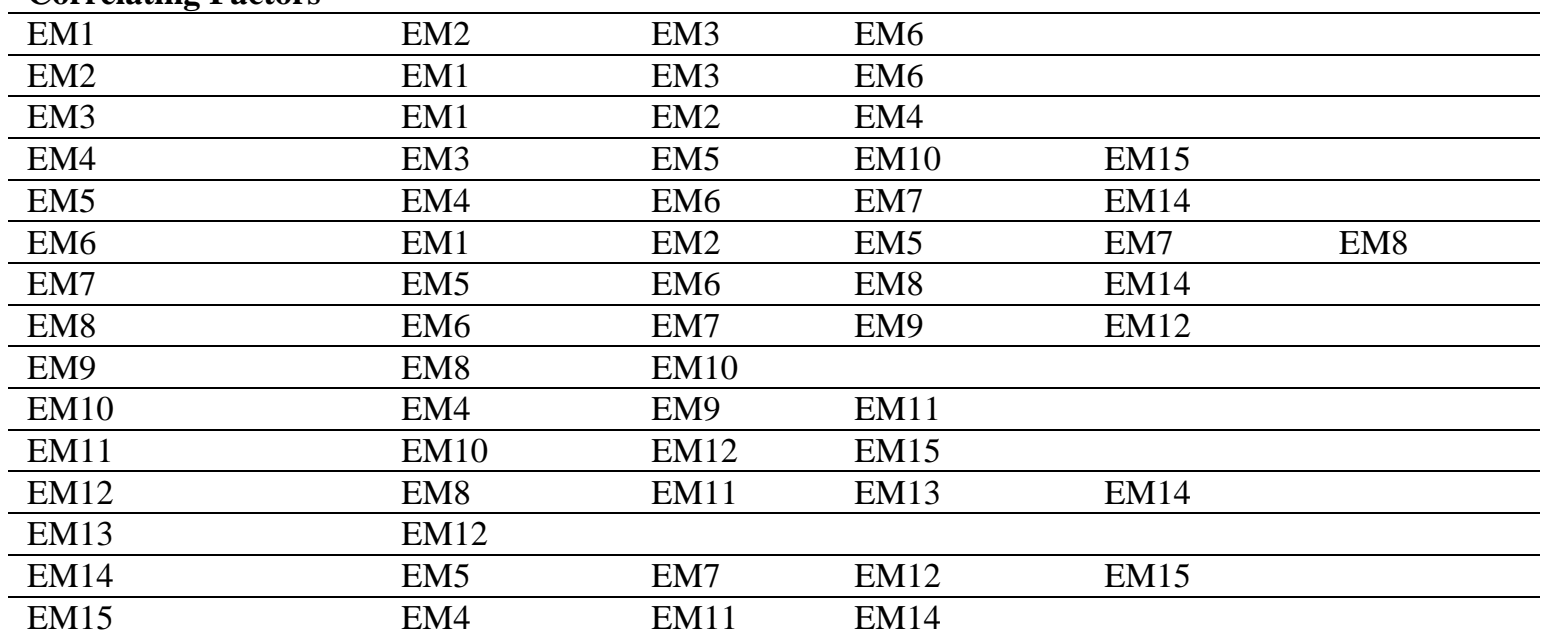

\section{Explanation:}

From the table of correlations, we drive a new table of moderate positive correlations. An analysis of the table of moderate positive correlations reveals that factor EM6 has positive moderate correlations with the most number of factors i.e., 5 factors. Furthermore, factors EM4, EM5, EM7, EM8, EM12 and EM14 have significant positive relationships with the second most number of factors i.e., 4. However, in order to determine predicting behavior amongst these factors we establish seven regression equations as under:

\section{Regression Model for Mediation Analysis:}

$E M_{6}=\beta_{1} E M_{1}+\beta_{2} E M_{2}+\beta_{3} E M_{5}+\beta_{4} E M_{7}+\beta_{5} E M_{8}+\beta_{6} E M_{12}$

$E M_{4}=\beta_{1} E M_{3}+\beta_{2} E M_{5}+\beta_{3} E M_{10}+\beta_{3} E M_{15}$

$E M_{5}=\beta_{1} E M_{4}+\beta_{2} E M_{6}+\beta_{3} E M_{7}+\beta_{4} E M_{14}$

$E M_{6}=\beta_{1} E M_{1}+\beta_{2} E M_{2}+\beta_{3} E M_{5}+\beta_{4} E M_{7}+\beta_{5} E M_{8}$

$E M_{7}=\beta_{2} E M_{5}+\beta_{2} E M_{6}+\beta_{3} E M_{8}+\beta_{4} E M_{14}$

$E M_{8}=\beta_{2} E M_{6}+\beta_{2} E M_{7}+\beta_{2} E M_{9}+\beta_{4} E M_{12}$

$E M_{12}=\beta_{1} E M_{8}+\beta_{2} E M_{11}+\beta_{3} E M_{13}+\beta_{4} E M_{14}$

$E M_{14}=\beta_{1} E M_{5}+\beta_{2} E M_{7}+\beta_{3} E M_{12}+\beta_{4} E M_{15}$

\section{Regression Analysis}

Table: 9

Model

Unstandardized

P-Values t-test

P-Values F-Test

Coefficients

\begin{tabular}{lll}
\hline (Constant) & 1.259 & 0.119 \\
\hline EM3 & 1.325 & 0.081 \\
\hline EM5 & 0.125 & 0.125 \\
\hline EM10 & 3.137 & 0.041 \\
\hline EM15 & 0.111 & 0.097
\end{tabular}

0.098

Dependent Variable: EM4

Table: 10

\begin{tabular}{|c|}
\hline Model \\
\hline
\end{tabular}

\begin{tabular}{lll}
\hline (Constant) & 0.137 & 0.091 \\
\hline EM4 & 0.333 & 1.137 \\
\hline EM6 & 0.212 & 1.111 \\
\hline EM7 & 0.127 & 2.227 \\
\hline EM14 & 5.125 & 0.010
\end{tabular}


Table: 11

Dependent Variable: EM5

Model $\quad \begin{aligned} & \text { Unstandardized } \\ & \text { Coefficients }\end{aligned}$

\begin{tabular}{lll}
\hline (Constant) & 3.129 & 0.011 \\
\hline EM1 & 5.756 & 0.000 \\
\hline EM2 & 2.813 & 0.019 \\
\hline EM5 & 3.123 & 0.031 \\
\hline EM7 & 0.729 & 2.122 \\
\hline EM8 & 8.191 & 0.000
\end{tabular}

P-Values F-Test

Dependent Variable: EM6

Table: 12

Model

Unstandardized

P-Values t-test

P-Values F-Test Coefficients

\begin{tabular}{lll}
\hline (Constant) & 0.717 & 1.911 \\
\hline EM5 & 1.124 & 0.085 \\
\hline EM6 & 3.917 & 0.021 \\
\hline EM8 & 1.325 & 0.047 \\
\hline EM14 & 0.925 & 0.311
\end{tabular}

0.073

Dependent Variable: EM7

Table: 13

\begin{tabular}{|c|c|c|c|}
\hline Model & $\begin{array}{l}\text { Unstandardized } \\
\text { Coefficients }\end{array}$ & P-Values t-test & P-Values F-Test \\
\hline (Constant) & 0.688 & 2.117 & 0.067 \\
\hline EM6 & 0.133 & 0.715 & \\
\hline EM7 & 3.217 & 0.042 & \\
\hline EM9 & 0.070 & 0.918 & \\
\hline EM12 & 4.770 & 0.006 & \\
\hline
\end{tabular}

Table: 14

\begin{tabular}{|c|c|c|c|}
\hline Model & $\begin{array}{l}\text { Unstandardized } \\
\text { Coefficients }\end{array}$ & P-Values t-test & P-Values F-Test \\
\hline (Constant) & 3.126 & 0.031 & 0.027 \\
\hline EM8 & 0.995 & 0.059 & \\
\hline EM11 & 6.845 & 0.008 & \\
\hline EM13 & 4.133 & 0.013 & \\
\hline EM14 & 1.913 & 0.045 & \\
\hline
\end{tabular}

\section{Table: 15}

\begin{tabular}{|c|c|c|c|}
\hline Model & $\begin{array}{l}\text { Unstandardized } \\
\text { Coefficients }\end{array}$ & P-Values t-test & P-Values F-Test \\
\hline (Constant) & 0.875 & 0.310 & 0.115 \\
\hline EM5 & 1.325 & 0.061 & \\
\hline EM7 & 0.227 & 0.917 & \\
\hline EM12 & 3.129 & 0.010 & \\
\hline EM15 & 0.915 & 0.091 & \\
\hline
\end{tabular}

\section{Table: 16}

\begin{tabular}{|c|c|c|c|}
\hline Model & $\begin{array}{l}\text { Unstandardized } \\
\text { Coefficients }\end{array}$ & P-Values t-test & P-Values F-Test \\
\hline (Constant) & 6.124 & 0.001 & 0.000 \\
\hline EM1 & 10.234 & 0.000 & \\
\hline EM2 & 5.678 & 0.010 & \\
\hline EM5 & 6.134 & 0.003 & \\
\hline EM7 & 1.117 & 0.048 & \\
\hline EM8 & 6.735 & 0.008 & \\
\hline EM12 & 4.374 & 0.007 & \\
\hline
\end{tabular}




\section{Discussion:}

In order to check sampling adequacy, we have applied KMO and Bartlett's Test with varimox rotation method the results of which have been given in table 2. KMO's value of 0.817 and significant value Chi-square of Bartlett's test shows that the sample is adequate for the purpose of our research. The test results of communalities have been reported in table 3 which are above 0.5 confirming the results of KMO and Bartlett's test about sampling adequacy. The reliability statistics have been reported in table 6 where the Cronbach's value of over 0.7 shows that the data has internal consistency and is reliable for the purpose of research. Table 7 reports correlation results and table 8 reports their interpretation tabular form. Table 8 reveals that the factors of entrepreneurial motivation are clearly divided into two groups, where one group is from factors EM1 to EM8 and the other group is from EM9 to EM15.

In order to determine the determinants of entrepreneurial motivation we focus on seven variables which have positive correlation with the most number of variables. In order to determine the combination of factors which may serve as the predictors of entrepreneurial motivational, we established seven alternative regression equations the results of which have been reported in table 9 to table 15. Analysis of results from table 9 to 15 shows that as observed in correlation table, the regression result of one regression equation from upper portion of table 8 where EM6 is the dependent variable and EM1,2,5,7,8 are independent variables have overall significant F-test value and one regression result from lower portion of table 8 where EM12 is the dependent variable and EM8,11,13,14 are independent variables have significant F-test value.

In the second step we conduct mediation analysis to test our mediating model. To achieve the objective, we applied regression models to test our mediation model. The results of regression have been reported in 16. The table reveal that EM6 fully and positively mediates the relationship between EM6 as dependent variable and EM1, EM2, EM5, EM7, E8. This is because taking EM12 as mediating has not only improved the value of F-test but has also improved the coefficient of all other independent variables included in the model. Results of mediation model have depicted in figure 2 and the acceptance/rejection of hypotheses have reported in table 17. 


\section{Figure 2: Mediation Model of Entrepreneurial Motivation Results}

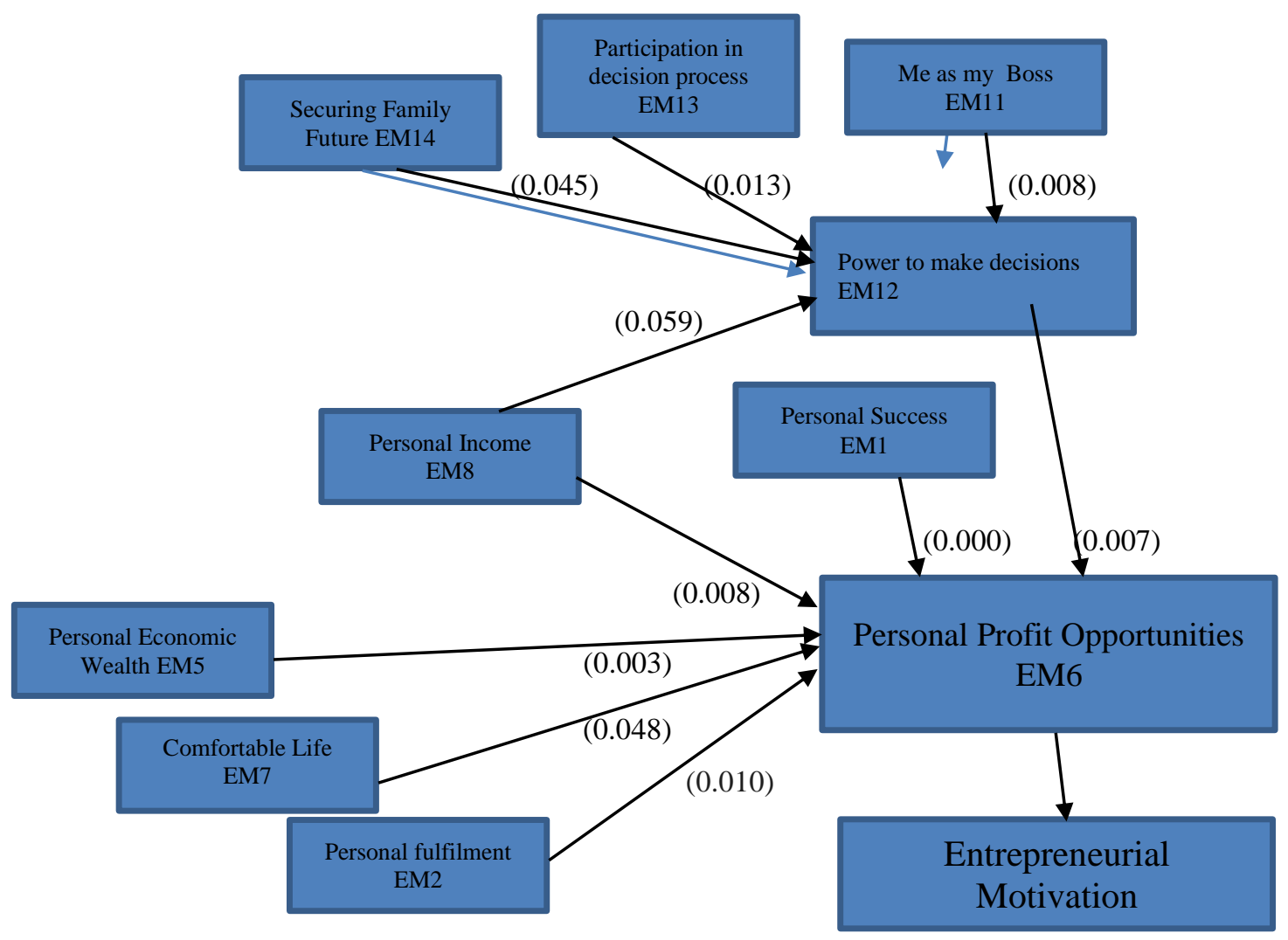

Table 17: Acceptance / Rejection of Alternative Hypotheses

\begin{tabular}{|c|c|}
\hline Hypotheses & $\begin{array}{l}\text { Acceptance / } \\
\text { Rejection }\end{array}$ \\
\hline $\begin{array}{l}\text { H1: Intention of the student to become his own boss positively effects } \\
\text { Entrepreneurial Motivation of the university students. }\end{array}$ & Accepted \\
\hline $\begin{array}{l}\text { H2: Intention of the student for participation in decision process positively } \\
\text { effects Entrepreneurial Motivation of the university students. }\end{array}$ & Accepted \\
\hline $\begin{array}{l}\text { H3: Intention of the student about securing family future positively effects } \\
\text { Entrepreneurial Motivation of the university students. }\end{array}$ & Accepted \\
\hline $\begin{array}{l}\text { H4: Intention of the student power to make decision positively effects } \\
\text { Entrepreneurial Motivation of the university students. }\end{array}$ & Accepted \\
\hline $\begin{array}{l}\text { H5: Intention of the student about personal success positively effects } \\
\text { Entrepreneurial Motivation of the university students. }\end{array}$ & Accepted \\
\hline $\begin{array}{l}\text { H6: Intention of the student about increasing personal income positively } \\
\text { effects Entrepreneurial Motivation of the university students. }\end{array}$ & Accepted \\
\hline $\begin{array}{l}\text { H7: Intention of the student personal economic wealth positively effects } \\
\text { Entrepreneurial Motivation of the university students. }\end{array}$ & Accepted \\
\hline $\begin{array}{l}\text { H8: Intention of the student about comfortable life positively effects } \\
\text { Entrepreneurial Motivation of the university students. }\end{array}$ & Accepted \\
\hline $\begin{array}{l}\text { H9: Intention of the student personal fulfilment positively effects } \\
\text { Entrepreneurial Motivation of the university students. }\end{array}$ & Accepted \\
\hline $\begin{array}{l}\text { H10: Intention of the student about personal profit opportunities positively } \\
\text { effects Entrepreneurial Motivation of the university students. }\end{array}$ & Accepted \\
\hline $\begin{array}{l}\text { H11: Intention of the student to become his own boss positively effects } \\
\text { Power to make decisions of the university students. }\end{array}$ & Accepted \\
\hline the student about partici & Accepted \\
\hline
\end{tabular}


positively effects Power to make decisions of the university students.

H13: Intention of the student about securing family future positively effects Accepted Power to make decisions of the university students.

H14: Power to make decisions of the student fully mediates the relationship Rejected between independent variables and Entrepreneurial Motivation amongst university students of Pakistan.

H15: Power to make decisions of the student partially mediates the Accepted relationship between independent variables and Entrepreneurial Motivation amongst university students of Pakistan.

\section{CONCLUSION}

The results of the study confirms that there exists a positive relationship between Entrepreneurial Motivation and personal success, personal income, personal economic wealth, comfort in life, personal fulfilment and personal profit opportunities. Furthermore, the factors Intention to become own boss, participation in decision making process, intention to increase personal income and securing personal future serve as independent variables for perception of the students for power to make decisions. Also our study confirms our hypothesis that perception of the students about power to make own decision serves as a factor that positively and partially mediates the relationship of Entrepreneurial Motivation of University students with all independent variables. The results of the study also suggest that intention of the students to increase personal income somehow plays dual role in the entrepreneurial motivation as firstly it has a direct impact on personal profit opportunities and then it also impacts through intention of the students about power to make decisions but here the impact is insignificant. This leads us to form a conclusion that entrepreneurial motivation amongst university students in Pakistan is a complex phenomenon that has two dimensions which are "psychological" and "economic". The factors in phycological category include "power to make own decisions", "intention to become own boss", "participation in decision process", "securing the future of the family", "personal success", "comfortable life" and "personal fulfilment". Whereas economic factors include "personal income", "personal economic wealth" and "personal profit opportunities". Furthermore, it can also be argued that the "power to make decisions" is a psychological phenomenon that partially mediates the entrepreneurial motivation of university students in Pakistan, though there exist other psychological factors that affect entrepreneurial motivation of university in Pakistani settings.

Novelty: This study has many novelties from various dimensions. Firstly, it encompasses universities from all over Pakistan, a diversified sample that never been explored before. Secondly, the novelty involves in the application statistical methods to identify various combination of variables to be explored for the purpose of identifying factors that contribute towards entrepreneurial motivation in university students in Pakistan. Thirdly, the novelty is identification of "psychological" and "economic" factors that affect the "entrepreneurial motivation" of university in Pakistan. Fourthly, the novelty is the identification of mediating role of certain "psychological factors" that impact "entrepreneurial motivation". A table numbered as table number 17 showing the acceptance rejection of hypotheses has been given hereinabove.

Economic Implications: This study has very important implications for a developing country like Pakistan. It can be helpful for resolving the rising unemployment problem that on what "psychological" and "economic" grounds university should be motivated to increase their acceptability and integration into the society. More entrepreneurs will more business setups generating more employment opportunities which will have more profound economic results compared to working as an employee.

Limitations and Future Research directions: This study suffers from various limitations. A study on similar dimensions with larger sample and different economic and geographic 
settings can be made to confirm results. Keeping in view the complexity future studies may also be carried out taking into account specific settings. For example, entrepreneurial motivation factors amongst the students of various disciplines, different genders, rural and urban areas, developed and developing countries from the perspective of psychological and economic factors.

\section{REFERENCES}

Adekiya, A. A., \& Ibrahim, F. (2016). Entrepreneurship intention among students. The antecedent role of culture and entrepreneurship training and development. The International Journal of Management Education, Vol.14 No.2, 116-132.

Ajzen, I. (1991), "The theory of planned behavior".Organizational Behavior and Human Decision Processes, Vol. 50 No. 2, pp. 1-63.

Amentie.C. and Negash E. (2014) the study on female under graduates attitude toward and perception on entrepreneurship development (comparison between public and private universities in Ethiopia). International journal of scientific and research publications, vol. 4, issue 12, December 2014. ISSN 2250-3153.

Bae, T. J., Qian, S., Miao, C., \& Fiet, J. O. (2014). The Relationship between Entrepreneurship Education and Entrepreneurial Intentions: A Meta-Analytic Review. Entrepreneurship theory and practice, 38(2), 217-254.

Colette, H. (2015),"Entrepreneurship education evaluation: revisiting Storey to hunt for the heffalump ", Education + Training, Vol. 57 Iss. 8/9, pp. 816 - 833.

Cope,H(2015), Toward a dynamic learning perspective of entrepreneurship, Entrepreneurial theory and practice, Vol. 57 Iss 8/9,pp. 816-833.

Edmondson, A. C., \& McManus, S. E. (2007). Methodological fit in management field research. Academy of Management Review, 32

Farhangmehr, M., Gonçalves, P., \& Sarmento, M. (2016). Predicting entrepreneurial motivation among university students: The role of entrepreneurship education. Education+ Training, 58(7/8), 861-881.

Franke, N., \& Lüthje, C. (2004). Entrepreneurial intentions of business students-A benchmarking study. International Journal of Innovation and Technology Management, 1(03), 269-288.

Garba, A. S., Kabir, S., \& Nalado, A. M. (2014). An assessment of students' entrepreneurial intentions in tertiary institution: a case of Kano State Polytechnic, Nigeria. International Journal of Asian Social Science, 4(3), 434e443.

Hassan, N. F. H. N., Jaafar, N. F. H. N., Ahmad, N., Ibrahim, N., \& Chek, W. A. K. W. (2018). The role of games card in active teaching and learning approach: a case study of Entrepreneurial Creative Card (EC-CARD). Journal of Fundamental and Applied Sciences, 10(4S), 829-842.

Ismail, K., Anuar, M. A., Omar, W. W., Aziz, A. A., Seohod, K., \& Akhtar, C. S. (2015). Entrepreneurial intention, entrepreneurial orientation of faculty and students towards commercialization. Procedia-Social and Behavioral Sciences, 181, 349-355.

Kadir, M. B. A., Salim, M., \& Kamarudin, H. (2012). The Relationship Between Educational Support And Entrepreneurial Intentions in Malaysian Higher Learning.

Lüthje, C. (2004). Entrepreneurial intentions of business studentsa benchmarking study. International Journal of Innovation and Technology Management, 1, 269e288.

Lüthje, C., \& Franke, N. (2003). The 'making'of an entrepreneur: testing a model of entrepreneurial intent among engineering students at MIT. R\&d Management, 33(2), 135-147.

Basu, A., \& Virick, M (2008) .Assessing Entrepreneurial Intentions Amongst Students: A Comparative Study, Peer Reviewed Paper, San Jose State University.

Mat, S. C., Maat, S. M., \& Mohd, N. (2015). Identifying factors that affecting the entrepreneurial intention among engineering technology students. Procedia-Social and Behavioral Sciences, 211, 1016-1022. 
Mohar,Y., Singh,M.S. and Kamal,K.K.(2007) Relationship between psychological characteristics and entrepreneurial inclination: a case study of students at University Tun

Muhammad, A. D., Aliyu, S., \& Ahmed, S. (2015). Entrepreneurial Intention among Nigerian University Students. American Journal of Business Education, 8(4), 239-248.

Neck,H. and Greene,P.(2011),Entrepreneurial education: known World and New frontier, journal of small business management, Vol. 49 No 1

Noor Hasnah, H. (2014). Factors influencing attitude towards entrepreneurship among higher education students at Universiti Kuala Lumpur, Malaysian Spanish Institute (Doctoral dissertation, Universiti Utara Malaysia).

Nwankwo, B. E., Kanu, G. C., Marire, M. I., Balogun, S. K., \& Uhiara, C. (2012). Genderrole orientation and self efficacy as correlates of entrepreneurial intention. European Journal of Business and Social Sciences, 1(No. 6), 09e26.

Obembe, E., Otesile, O., \& Ukpong, I. (2014). Understanding the students' perspectives towards entrepreneurship. Procedia-Social and Behavioral Sciences, 145, 5-11.

Rasli, A., Khan, S. U. R., Malekifar, S., \& Jabeen, S. (2013). Factors affecting entrepreneurial intention among graduate students of Universiti Teknologi Malaysia. International Journal of Business and Social Science, 4(2).

Schlaegel, C., \& Koenig, M. (2014). Determinants of Entrepreneurial Intent: A MetaAnalytic Test and Integration of Competing Models. Entrepreneurship Theory and Practice, 38(2), 2291-332.

Thompson, E. R. (2009). Individual entrepreneurial intent: Construct clarification and development of an internationally reliable metric. Entrepreneurship Theory and Practice, May, 669-694.

Van Gelderen, M., Brand, M., van Praag, M., Bodewes, W., Poutsma, E., \& Van Gils, A. (2008). Explaining entrepreneurial intentions by means of the theory of planned behaviour. Career Development International, 13(6), 538-559.

Wang, C. K., \& Wong, P. K. (2004). Entrepreneurial interest of university students in Singapore. Technovation, 24(2), 163-172.

Yurtkoru, E. S., Kuşcu, Z. K., \& Doğanay, A. (2014). Exploring the antecedents of entrepreneurial intention on Turkish university students. Procedia-Social and Behavioral Sciences, 150, 841-850. 